\title{
Leadership for integrated care: a case study
}

Purpose: Integration of health services involves multiple interdependent leaders acting at several levels of their organisation and across organisations. This paper explores the complexities of leadership in an integrated care project and aims to understand what leadership arrangements are needed to enable service transformation.

Design/Methodology/Approach: This case study analysed system and organisational leadership on a project aiming to integrate primary and specialist care. To explore the former, the national policy documents and guidelines were reviewed. To explore the latter, the official documents from the transformation team meetings and interview data from seventeen healthcare professionals and commissioners were analysed using thematic analysis with the coding framework derived from the comprehensive and multilevel framework for change.

Findings: Although integration was supported in the narratives of the system and organisational leaders, there were multiple challenges: 1) insufficient support by the system level leadership for the local leadership, 2) insufficient organisational support for (clinical) leadership within the transformation team, and 3) insufficient leadership within the transformation team due to disruptions caused by personnel changes, roles ambiguity, conflicting priorities, and insufficient resources.

Practical implications: This study provides insights into the interdependencies of leadership across multiple levels and proposes steps to maximise the success of complex transformational projects.

Value: This study's practical findings are useful for those involved in the bottom-up integrated projects, especially the transformation teams' members. The case study highlights the need for a toolkit enabling local leaders to operate effectively within the system and organisational leadership contexts.

Key words: health service transformation, healthcare integration, leadership for integration, case study 


\section{Introduction}

\section{Changes in the health systems and the need for closer working together}

Many health systems look towards intensifying joint working between health services to solve the deepening divisions in the provision of healthcare. These divisions are linked to the growing number of care pathways spanning multiple organisations that patients with complex long-term conditions and multimorbidity struggle to navigate. As a result, care is fragmented and episodic resulting in delays, duplications and gaps (WHO, 2016). This leads to reduced safety, quality, experience, and affordability of healthcare (Stange, 2009). These challenges highlight a growing need for health services to work across organisational and professional boundaries.

To achieve better coordination of care, many health services pursue integration to a varying extent ranging from linkage, through collaboration to full integration with the latter being recommended for organising care for people with severe, complex and long-term needs (Leutz, 1999). Full integration is characterised by multidisciplinary teams managing all care in all key settings using one health record as part of a daily joint practice, pooling funds to purchase all services and sharing benefits (Leutz, 1999, 86-87), and owning the health outcomes of patients (Diabetes UK, 2013). The ambition is for the join between different parts of the health system to be invisible for patients as if they were in contact with a single organisation (Irani, 2008, p.11).

Integration is a complex transformational project; those involved are faced with an adaptive challenge (as opposed to a technical problem) (Heifetz, Linsky \& Groshow, 2009) and dynamic complexity (as opposed to detail complexity) (Senge, 1990). While a technical problem is a problem that can be solved with knowledge and procedures already in hand, an adaptive challenge requires new learning, innovation, and new patterns of behaviour (Parks, 2005). While detail complexity refers to problems with many variables, a dynamic complexity refers to situations where cause and effect are subtle and uncertain with the same solutions having dramatically different effects in short vs long term and locally vs other locations (Senge, 1990). The process of integration may experience a variety of barriers since it asks different service providers to give up their independence to some degree, change the established ways of working, and balance conflicting expectations of their own organisations and the new integrated service (Kozlowska et al., 2018).

The leadership for integrated care has to recognise that the task it is facing cannot be approached as a technical problem limited to detail complexity, but rather an adaptive challenge within a dynamic complexity; indeed, it needs to develop new solutions while working in unpredictable environment. Pursuing such challenge requires a particular form of leadership. 'Leadership' described as a process whereby a person influences others to achieve a common goal (Northouse, 2007, p.3) seems to be focused on 'a person' only while the efforts of an individual or a few individuals leading on integration have to be placed in the context of the whole system (Baker, 2011). 'Leadership' becomes an effort on all levels of the healthcare system where action is required to support change and therefore a leadership structure is a complex one spanning from the government (with their position on integration expressed in policies, regulations and recommendations) to the individuals at the forefront of healthcare delivery.

This case study explores the leadership arrangements in developing an integrated diabetes service across primary, community and specialist care. It looks at leadership for integration at the system and organisational levels of change and the factors enabling and hindering effective leadership. In particular the leadership of the transformation team is analysed, the transformation team being a group of individuals representing the stakeholders in the meetings to work out the details of integration. While there is a recognition of how important leadership is to healthcare integration, with some guidance on effective leadership styles and skills (e.g. the King's Fund, 
2016; the King's Fund, 2015; Timmins, 2015; West et al., 2015a; West et al., 2014b; Ferlie and Shortell, 2001), there is very little literature providing insight into the practicalities of setting up and supporting an effective leadership system.

\section{Theoretical background}

\section{Leadership in the health systems undergoing integration}

Delivering integration of services needs to include change at a system, organisational, team and individual level with leadership fully embedded at every level (Ferlie and Shortell, 2001). Regarding the leadership to be embedded, it has been proposed for the framework for leadership to shift its focus from three entities 'leaders, followers and shared goals' to three leadership outcomes 'direction, alignment and commitment' with the latter framework being seen as more adequately supporting understanding of leadership in the context where collaboration is expected or required (Drath et al., 2008). The three leadership outcomes have been described as:

- 'direction' - the agreement on the overall goals, aims and mission

- 'alignment' - the coordination of actions towards achieving the goals

- 'commitment' - the willingness to subsume own efforts and benefits within the shared ones (Drath et al., 2008).

For transformation to succeed, leadership has to have 'direction, alignment, and commitment' embedded throughout the system (Aarons et al., 2014; Lejeune \& Vas, 2011), with support for change and coordinated action to implement the new ways of working at all levels:

- System level: political leaders and the government must provide an environment that is conducive to change in relation to payment and regulatory policies.

- Organisational level: organisational leaders must establish a vision for change, provide a supportive environment with the necessary resources, and insist on accountability for results.

- Team level: groups and teams must assume leadership to implement the characteristics of effective teams.

- Individual level: the individual clinicians, managers, and policy makers need to change practice (adapted from Ferlie and Shortell, 2001).

The framework for whole system change (Ferlie and Shortell, 2001) felt to recognise a change agent. This could be a transformation team consisting of individuals representing the stakeholders and tasked with negotiating the vision for change, service specifications and implementation process. It is in this setting that the change leaders are likely to emerge and flourish or struggle depending on their leadership qualities, leadership arrangements within the team, the support of middle and upper organisational management and the enabling of system leadership at a local level. Since clinical leadership has been given a key role with unprecedented responsibility in the NHS (Health and Social Care Act, 2012; NHS Improving Quality, 2013; NHS Leadership Academy, 2011) it is very likely that clinicians will be a key part of the transformation teams and play a vital role in the process.

Clinically driven leadership needs to be fit for integration, bringing together stakeholders from different organisations. It has been proposed that change leaders should work within a distributed leadership model, building a coalition of like-minded people dispersed across the different organisations who could influence change using their legitimacy, authority, and resources (Chreim et al., 2010; The King's Fund, 2011, p.22). There is some literature recognising the importance of adapting an adequate leadership style for integration (West et al., 2015; Fillingham and Weir, 2014; NHS Leadership Academy, 2011; Chreim et al., 2010). However, those working on the integration projects are faced with a difficult task with little or no guidance. Advice on how to organise transformation teams to enable clinically driven leadership, develop effective multi-organisational leadership, and secure support for the project at the organisational and system levels, are a rarity within the field of service transformation (e.g. Lejeune \& Vas, 2011). More practical guidance is needed to support those driving change including clinicians. 
This case study of integrating diabetes primary and specialist care highlights the need for such guidance and toolkit.

\section{Method}

\section{Using the case study method to explore the process of service integration}

Case study methodology is well suited to the exploration of the process of service transformation as it allows in-depth, multi-faceted explorations of complex issues in their real-life settings (Yin, 2009). Case study approach lends itself well to exploring integrated care projects in that they are complex, entangled, multi-faced affairs, initiated in response to different needs and delivered to varying specifications, timeframes, and resources (Crowe, 2011; Sanfey, 2017). It can offer insights into the pre-implementation stages of service transformation when the options are discussed and decisions made and more exploratory approach is needed to answer the "what, how and why' questions enhancing understanding of the factors responsible for successes and failures of the service transformation projects.

\section{Contextually bound intrinsic/instrumental case study}

The current study covers a single integrated diabetes care project. It was analysed in the third year of intense work on the project and with the new integrated diabetes service not yet commissioned. The primary focus of the study was to explore the factors enabling and hindering the process of integration and this paper focuses on the role of leadership in the process. Initially the study was an intrinsic case study to investigate the processes within the ongoing integrating diabetes care project, however it developed into an instrumental case study seeking to gain a broader appreciation of leadership for integration and generate a number of findings potentially transferable to other projects with similar characteristics. Other projects may be assessed as comparable if pursuing 1) full integration, 2) between primary and specialist care, and 3) bottomup driven (other criteria for comparison available in Calciorali et al., 2011).

Diabetes care is a good example to study integration as diabetes care is provided across healthcare professions and organisations with some patients coming in contact with up to nine healthcare professionals ${ }^{1}$ and more if they develop complications from diabetes. The integrated diabetes care project analysed in this study begun in 2014 with an aim of developing a fully integrated diabetes service within Oxfordshire. Its aim was to address the growing demand for diabetes care, provide more person-centred care, improve the overall outcomes of care, and address variation in quality of care across the region while improving use of resources. Multiple organisations were involved in providing primary and specialist (secondary and community) diabetes care commissioned, funded and managed in different ways and using separate electronic patient record systems.

The drive for integration came from the patients and the clinical team and the transformation team was established to determine the specifications of the new service and secure buy-in from all stakeholders including commissioners and service providers from primary care (70 general practices), community care and secondary care. The responsibility for hosting and organising the meetings was taken by Oxfordshire Clinical Commissioning Group (an organisation that plans, buys and oversees health services) working for 700,000 residents of the county with estimated $5 \%$ living with diabetes. The transformation team consisted of nearly twenty members representing patients, commissioners, and all service providers of diabetes care with this number fluctuating throughout the project. After three years of work and full integration not quite implemented, the transformation team decided to pilot elements of the new service in one primary care locality following its clinical lead's proactive engagement with the transformation

${ }^{1}$ https://www.diabetes.org.uk/guide-to-diabetes/managing-your-diabetes/interactions-with-healthcareprofessionals 
team and declaring the locality's readiness to proceed; this project required input from the clinical commissioning group, seven primary care practices in the pilot locality and a GP Federation providing legal and organisational support for them, a specialist diabetes team based in a Hospital Trust and a diabetes specialist nurses team based in a Community Trust.

\section{Collecting and analysing the data}

Thirty three policy and regulation documents published between 2006 and 2016 were identified and analysed by the researcher (OK) to understand the extent of the system level leadership for integration of health care. In addition, a wider set of official recommendations and proposals by patient organisations and medical associations providing leadership to healthcare professionals involved in service redesign was investigated. Further six documents on local policy on integration were identified and analysed.

Further data came from two sources, 1) the official minutes and documents of the project's transformation team, and 2) the interviews with those participating in transformation of the diabetes service in the county. A group of seventeen respondents involved in planning, implementing and delivering the new service were interviewed including the patient representative, three senior management-leaders (representing the clinical commissioning group, the hospital trust, and the community trust), the clinicians on the transformation team (including front-line health professionals: three consultants in diabetes, one specialty diabetes nurse, one mental health specialist, and two clinical leads for long-term conditions) and the pilot locality team (including the locality clinical lead and three general practitioners and two practice nurses from seven general practices). Semi-structured interviews were used to capture their perception of the process of change and the role of and qualities of leadership in this process. The interview schedule consisted of ten questions aiming to identify if leadership was seen by the interviewees as one of the key factors in transformation and to grasp the interviewees' understanding of what leadership was through analysis of their experiences of leadership, what role leadership played in their service, and what leadership skills they saw as necessary to deliver integrated service. The interviews were collected by researchers (GS and $\mathrm{OK}$ ).

The study applied the comprehensive and multilevel framework for change (Ferlie and Shortell, 2001) to describe the leadership system and to examine if, and to what extent, leadership was secured with 'direction, alignment, and commitment' achieved throughout the system. Although the need for change to happen at all four levels is recognised, with leadership at system, organisational, team and individual levels, this case study focused on the system and organisational levels with the addition of the transformation team level which previously has not been well explored in the literature. Leadership at the team (healthcare professionals providing care to the same patient) and individual (individual healthcare professionals) levels were not within the remit of this study with the project being in the initiation stage of service transformation prior to implementation.

\section{RESULTS}

The results are presented by the healthcare level: system, organisation and transformation team. For each level, a goal (the role of leadership at a specific level in achieving diabetes integrated care in Oxfordshire), a current status (what is being delivered to support integrated care), a source of data, and findings are presented. In the findings, the extent of embedding leadership and securing 'direction, alignment, and commitment' is assessed and its impact on the integrated diabetes care project.

Leadership at the system level - the gap between the narrative and reality of supporting healthcare integration 
At the time of developing the integrated diabetes care project, multiple national policies were promoting integrated care. The approach to designing and implementing the new models of care adopted by the leaders for integration at the system level was flexible meaning that the regulatory, financial and incentive solutions were not readily available with local organisations encouraged to develop their own solutions.

Table 1.

\begin{tabular}{|c|c|c|c|}
\hline Goal & Current status & Source of data & Findings \\
\hline \multirow{3}{*}{$\begin{array}{l}\text { leadership at the system level } \\
\text { to provide support to local } \\
\text { integrated care initiatives }\end{array}$} & $\begin{array}{l}\text { expressing imperative to } \\
\text { provide integrated care }\end{array}$ & public policy documents & \multirow{3}{*}{$\begin{array}{l}\text { The system leadership } \\
\text { empowered the local leaders } \\
\text { (calling for integration) but } \\
\text { did not provide sufficient } \\
\text { regulatory, financial and } \\
\text { incentive solutions for the } \\
\text { studied integrated care } \\
\text { programme. The flexible } \\
\text { approach was challenging for } \\
\text { some at the organisational } \\
\text { level not ready to take a risk } \\
\text { attached to the new solutions. } \\
\text { The identified funding } \\
\text { enabled support of only some } \\
\text { elements of the new } \\
\text { integrated diabetes service. }\end{array}$} \\
\hline & $\begin{array}{l}\text { promoting a flexible national } \\
\text { approach to regulatory, } \\
\text { financial, and incentive } \\
\text { solutions to enable } \\
\text { development of local } \\
\text { solutions }\end{array}$ & \multirow[t]{2}{*}{$\begin{array}{l}\text { transformation team's } \\
\text { documents: business cases }\end{array}$} & \\
\hline & $\begin{array}{l}\text { awarding transformation } \\
\text { funding to some but not all } \\
\text { local integrated care } \\
\text { initiatives }\end{array}$ & & \\
\hline
\end{tabular}

\section{The public policy statements on healthcare integration}

The search for the public policy statements on healthcare integration resulted in identifying thirty three documents (appendix 1). These included Acts of the Parliament, guidance from the Government to NHS England, NHS strategy and planning documents, provider licence obligations established by Monitor (regulating NHS foundation trusts), recommendations from the NHS Future Forum (an independent group reporting to the government) and the National Voices (the patients' perspective), and reports published by the healthcare professional organisations. There was a national imperative to provide integrated care across the health services. New models of care, requiring organisational changes to break down existing barriers between services, were expected to provide more person-centred, proactive and cost-effective care, and to reduce emergency hospital admissions (NHS England, 2014). In order to achieve this, the policy documents pledged strengthening system leadership for new care models and supporting local leadership and local solutions (NHS England, 2014). It advocated that the local initiatives could succeed only if operating in a regulatory, financial and incentive system that is conducive of collaboration. Local leaders pushing for change, would be empowered with a set of enablers to develop governance structures promoting care coordination.

\section{Implementing the national policies - the integrated care projects}

NHS England initiated a number of national programmes to support integration of care. These included sites nominated to implement the new care models specified in the Five Year Forward View (50 vanguard sites, 20 integrated care pioneers (ICPs), and primary care home model) and the sites applying for the transformation funds to develop new models of care under the NHS England Sustainability and Transformation Plans. The vanguard sites and ICPs had additional resources to develop and test the new models while other sites in need of integration were left to deliver change with their own resources. In addition, the Sustainability and Transformation Plans (STPs) were developed covering the whole of England. These were five year plans covering all aspects of NHS spending, developed between commissioners and service providers. The plans 
had to promote collaboration and the awarded organisations in order to receive funds for transformation. It is difficult to evaluate the benefits of these programmes with early evaluations indicating a mix of expected and unexpected outcomes (Morse, 2018; Erens, 2017 and NHS England, 2014a; RAND Europe, 2012). Other sites interested in integrating care were supported by individual healthcare professional bodies (e.g. the Future Hospital development sites, RCP, 2017), while some sites pursued integration independently.

In the case of the studies project, the system leadership empowered the local leaders (calling for integration) but did not provide sufficient support for the programme. It was not one of the NHS England supported sites and therefore did not initially have additional funding. The local STP plan was developed with engagement from the same organisations as those involved in the provision of diabetes services which resulted in the integrated diabetes care transformation team re-thinking the diabetes service and aligning it with the local STP. However no additional resources were provided. The project benefited from the NHS Diabetes transformation fund (awarded mid 2017) which increased collaboration through multidisciplinary team meetings across primary, secondary and community care but was insufficient to fund full integration.

The country-wide push to integrate care with the national leadership supporting the integration projects was expressed by providing a narrative making integration a requirement when considered to be key to provision of good quality care and by funding the new care models development and testing sites. With new solutions under development, there remained significant gaps regarding regulatory and payment advice.

\section{Gaps at the system level}

Split regulatory system It was planned that the regulatory bodies (the Monitor, NHS England Trust Development Authority and NHS England) would work together to create greater alignment between their respective local assessment, reporting and intervention regimes for healthcare providers and commissioners, complementing the work of the Care Quality Commission and the Health Education England (the Five Year Forward View, 2014). During this study, the services providing diabetes care were still measured against different outcomes with Care Quality Commission looking at each service separately.

Inadequate payment system In terms of integrating payment systems, the funding of the NHS remained split between primary and secondary healthcare services. This was of special importance to the project since it covered primary and specialist diabetes care. Practice based commissioning, payment by results, plurality of providers, and the opposite priorities for demand management, led to a deterioration in relationships and a growing mistrust between GPs and consultants, managers and clinicians, primary care trusts and hospitals, hindering seamless care along patient pathway (Irani, 2018). In the second decade of the 21 st century, the need for transforming services for those with a long term condition(s) and ensuring that payment systems and other incentives reward improve quality and support integrated services were reinforced (DH, 2009, 1.42). The system level leadership was lagging behind, it was proposed to link payment systems with whole pathways of patient care so that providers have incentives to keep patients with long-term conditions healthy and prevent unplanned and unnecessary admissions (DH, 2009, 4.7). Still, the same document linking payment systems with the whole care pathways made $10 \%$ of hospitals' income dependent on patients' experience and satisfaction with hospitals' service without linking it with the rest of the pathway sending a message of separate incentives driving the individual services. More integrated-friendly solutions were published later in $2015^{2}$ to be further tested (NHS England, 2016 a,b) with some concerns raised

${ }^{2}$ Different payment approaches to support new care models. Collection. 
at the national level by the healthcare professional organisations regarding the new contractual arrangements (BMA, 2017a,b).

\section{Leadership at the organisational level - navigating complex leadership and management arrangements}

The local policies relevant to integration of diabetes care were an indication of the organisational level leadership for the project. Together with the reassurance of support for the project, secured by the transformation team members from the chief executives and some of the executive directors across the organisations, the leadership for the project seemed to be secured at this level. However, it transpired that the support was less explicit at upper and middle management levels responsible for operational and day-to-day management of the services.

Table 2.

\begin{tabular}{|c|c|c|c|}
\hline Goal & Current status & Source of data & Findings \\
\hline \multirow[t]{4}{*}{$\begin{array}{l}\text { leadership at the } \\
\text { organisational level to } \\
\text { provide support to the } \\
\text { transformation team leading } \\
\text { on integrated care project }\end{array}$} & $\begin{array}{l}\text { all participating } \\
\text { organisations had integration } \\
\text { of healthcare in their } \\
\text { strategic objectives }\end{array}$ & local policies & \\
\hline & $\begin{array}{l}\text { the reassurance of support for } \\
\text { the project from the chief } \\
\text { executives and some of the } \\
\text { executive directors }\end{array}$ & \multirow[t]{3}{*}{$\begin{array}{l}\text { transformation's team } \\
\text { documents }\end{array}$} & $\begin{array}{l}\text { unclear leadership structure } \\
\text { and no clear decision making } \\
\text { pathway to enforce decisions } \\
\text { made by the transformation } \\
\text { team }\end{array}$ \\
\hline & $\begin{array}{l}\text { support less explicit at senior } \\
\text { and middle management } \\
\text { levels }\end{array}$ & & $\begin{array}{l}\text { although there was a positive } \\
\text { climate for change, the } \\
\text { transformation team was not } \\
\text { supported sufficiently by all } \\
\text { organisations to effectively } \\
\text { progress to implementation } \\
\text { of full integration }\end{array}$ \\
\hline & $\begin{array}{l}\text { senior/middle management } \\
\text { leadership vs clinical } \\
\text { leadership }\end{array}$ & & $\begin{array}{l}\text { the clinical/management } \\
\text { leadership split left the } \\
\text { clinical leads in an unequal } \\
\text { position with some having } \\
\text { more support than others and } \\
\text { therefore the project not } \\
\text { being pursued in a similar } \\
\text { way across three } \\
\text { organisations }\end{array}$ \\
\hline
\end{tabular}

\section{Upper level leadership}

Locally, there was a drive to coordinate services better. There was leadership for change coming from the chief executives of all three organisations as the prospect of integrated diabetes service was aligned with the vision for the local health economy. All organisations had integration of healthcare and bringing care closer to home in their strategic objectives published in 2013 and were contributing to the Sustainability and Transformation Plan since 2013 and the Oxfordshire Transformation Programme since early 2015. The latter was focused on improving healthcare across acute hospital services and community. Encouraging was a success of another initiative, integrated mental health service and the community trust signing an alliance contract with primary care in the county, indicating real commitment of the stakeholders to integration. There was leadership for integration secured at the highest organisational level of all organisations involved (as expressed in the strategic documents, appendix 2) and for the integrated diabetes 
project (as expressed informally by all chief executives to the members of the transformation team) but no aligned leadership at other levels of change within and across the organisations.

Without the senior management's continuous involvement and full support across all organisations, the progress was hindered. The lack of senior management leadership was a significant risk to the project as the senior level managers had responsibility for assessing the value of the project against the national and local priorities and resources, and therefore, as the decision makers, they were key to the project. The project lacked resources to develop the case for change (collect and analyse evidence from all organisations equally), the project support for members of the transformation team in all organisations, and the resources for implementation of the new service putting the project's future at risk.

\section{Unclear leadership structure}

Initially, it was unclear what the structure of leadership across organisations was. It seemed that the structure was complex with different leaders taking different formal or less formal roles across the organisations with clinical and managerial leadership not clearly defined or aligned. On one hand there was a hierarchical leadership system in each organisation linked to a managerial and a decision making structure. And on the other hand there was an unclear leadership configuration within the transformation team without a clear internal and external (with the team members' respective organisations) communication.

Senior/middle management leadership vs transformation team leadership

This was complicated further by lack of clear communication pathways between the senior/middle management and transformation team and therefore, there was no clear decision making pathway to enforce decisions made by the transformation team:

What we don't have in the group [the transformation team] is someone from the xxx management, because it is not only us selling it clinically but also xxx selling it back to its management.

The area we are probably lacking is driving the importance of diabetes at the clinical commissioning group [...]

Senior/middle management leadership vs clinical leadership

An additional challenge was lack of clarity how clinical leadership was aligned with management leadership. Not all clinical leads, members of the transformation team, were supported with the visible presence of their corresponding management leads. Additionally, not all of them were empowered with project management and resources. The clinical/management leadership split left the clinical leads in unequal position with some having more support than others and therefore the project not being pursued in a similar way across three organisations.

In overall, although there was a positive climate for change, the transformation team was not supported enough by all organisations to effectively progress to implementation of full integration.

\section{Leadership at the transformation team level - unclear leadership arrangements within the team}

The drive to improve the way diabetes care is organised came from those providing and those receiving diabetes care. Together, they formed a transformation team, a group working on the specifications of the integrated service, with input from all organisations providing diabetes care.

Table 3.

\begin{tabular}{|l|l|l|l|}
\hline Goal & Current status & Source of data & Findings \\
\hline
\end{tabular}




\begin{tabular}{|c|c|c|c|}
\hline \multirow{4}{*}{$\begin{array}{l}\text { leadership at the } \\
\text { transformation team level } \\
\text { supporting development and } \\
\text { implementation of the } \\
\text { integrated care service }\end{array}$} & $\begin{array}{l}\text { limited decision power, } \\
\text { going in motions }\end{array}$ & \multirow[t]{4}{*}{ interviews } & $\begin{array}{l}\text { unclear role of the } \\
\text { transformation team }\end{array}$ \\
\hline & $\begin{array}{l}\text { confusion among the team } \\
\text { members }\end{array}$ & & $\begin{array}{l}\text { unclear leadership within the } \\
\text { team }\end{array}$ \\
\hline & tensions within the team & & competing agendas \\
\hline & $\begin{array}{l}\text { frustrations and } \\
\text { disengagement within the } \\
\text { team }\end{array}$ & & $\begin{array}{l}\text { functioning in an unstable } \\
\text { environment }\end{array}$ \\
\hline
\end{tabular}

Unclear role of the transformation team

The role of the team and its members during the team meetings (representing their individual organisations) and outside of the meetings (representing the views of the transformation team) were vague making it difficult for the team leadership to develop and effectively drive the change influencing the organisational level leadership. It was not clarified what the decisionmaking power of the team was - who was the ultimate decision maker on what issues related to the specifications of the new integrated service, its implementation and evaluation. The actions within the team might have given an impression that the team or its members had the right to make the decisions while it was not necessarily the case with the senior management not involved.

One of the indicators of lack of clarity on the team's role was a changing name given to the team by a sequence of newly appointed commissioners hosting the meetings throughout the project: Clinical Advisory Group Diabetes Commissioning Pilot, Integrated Diabetes Transformation Team, Diabetes Project Board (accompanied by Diabetes Task and Finish Group).

\section{Unclear leadership within the team}

The leadership arrangements within the team were initially not well defined. After three years of working together, the team members hold assumptions about who the leader on the team was (whether it was them or someone else) and whether there was a need for a single leader or a group of leaders, and what their roles would be:

Who is the leader? It is a good question. There is a little bit of a void I think. I think that the leader is meant to be me, who is driving it forward, and I think that I am happy to take it on. I think that the challenge is that if there is a single leader, there is only so much I can achieve. So actually I can be the clinical lead, but what I can't be is the management lead, so I have a corresponding management lead and then I think we probably need leaders in each organisation and each setting as well. So I don't think it is like a unitary person that need to be a leader.

Is there leadership? In the beginning, I did see one person a leader, the emphasis seems to switch a little bit to someone else, I was hoping that the strong leadership would come from that source. At the moment I don't feel that the leadership is strong and there have been too many personnel changes for me to feel that there is a strong leadership. [We need leadership that is] inspirational, focused, determined, ambitious, collaborative, and not just going through the motions.

It is vague, the structure and accountability of the group; people change, it was a bit unclear what the leadership structure was, even on practical level - who would chair a meeting, slightly awkward and not explicit enough.

Tensions within the team - managing competing agendas

Establishing a shared vision for the new service and working together towards making this vision a reality meant working with commissioners, clinicians of different clinical and managerial 
responsibilities, clinicians embedded in different cultures and driven by respective organisational priorities. This created tensions and managing them without clear leadership was challenging. The team members were aware of the tensions and of the importance of involving everybody, listening to all stakeholders, and balancing different agendas (priorities and timescales):

I think there will always be tensions between the people who are in commissioning and managing roles who want to manage the process to get the results delivered as quickly as you can and the people who are clinicians who are delivering it trying to get the balance realistic time scale and not letting the thing wallow and not deliver. But I think it is a constructive tension.

We have the right people around the table. It is hard to know how truly invested every single person is. And we have to make sure that we work to keep everyone feeling that they are fully involved. And it is a difficult task of managing this type of transformation. And we need to balance different agendas.

You need some sort of vision to be able to say look, this is the vision that we have and to be able to sell that and motivate people in order to buy that. Listen to competing demands, there are different stakeholders, and each of the stakeholders has their own personal interests. And obviously everyone cares about the patient but then care about their role.

Predictably doctors do all the talking. [One of the doctors] manages people who talk too much and he actively involves people who are not contributing. Being actively asked your view about something makes you feel more valued, everybody makes a contribution and it is a particular skill.

Vulnerability in face of challenges - managing an unstable environment

A lack of clear leadership, and a clear vision shared by everybody, made the programme vulnerable in face of problems that came along, namely the personnel changes on the transformation team, the changes in priorities across organisations, the changes in the proposed model of integrated diabetes service, and prolonging life of the project beyond initially proposed framework. The project survived and the team kept meeting but there was a growing confusion and frustration.

Frustrations within the team - managing disengagement

Full integration, being a complex transformation, carries a risk of being delayed, causing frustration and disengagement among the stakeholders. Leaders, focused on the final monumental goal may overlook opportunities of bringing stakeholders together by delivering small-scale changes (e.g. 'connected mini-transformations, Kelley-Patterson, 2012). On the studies project, there was a shared feeling that the transformation "was going slowly" and a concern that it might come to a halt. It took some time for the leaders to recognise and communicate within the team that delivering sustainable improvement may be a long process and what is needed to maintain engagement are:

Smaller tasks, shorter timeframe, something positive coming out of it.

This realisation encouraged the team to apply for smaller funding, to introduce elements of integrated care to pilot solutions and highlight the positive aspects of working together, and finally - proceed to a bigger pilot and continue working towards the full integration.

\section{DISCUSSION}

The case study provided insights into the complexities of and challenges to leadership during an integrated care project being an adaptive challenge (Heifetz, Linsky \& Groshow, 2009) within a context of dynamic complexity (Senge, 1990). The study revealed how a service transformation 
project aiming to integrate primary and specialist care can be hindered if leadership is not fully embedded at its multiple levels and the higher level leadership does not enable effective leadership at the lower levels. While 'the direction,' the narrative supportive of integrated healthcare was present across all leadership levels, the leadership arrangements and regulation/payment/financial tools for integration did not necessarily followed. The alignment was lacking at the system and organisational levels with inefficient resources being provided for leaders at the lower levels, and the commitment was not secured at the organisational level (especially senior and middle management) and was not consistent among the members of the transformation team. The commitment at the system level was difficult to conceptualise unless the flexible approach to the payment and regulatory solutions was a sign of readiness to surrender own powers to enable local innovation in a more independent climate.

\section{Rhetoric and reality of healthcare integration}

Analysis of leadership at the system level revealed that the rhetoric of integration existing at the system level was not always reflected in regulatory, financial and incentive solutions available. Some of the policy barriers identified by other integrated care programmes across England in the first decade of the 21 st century, including perverse incentives, inadequate commissioning, and the negative impact of regulation (Ham and Smith, 2010) were still relevant to the integrated diabetes care project years after. Regarding perverse incentives, the incentives rewarded individual services (payment by result) without rewarding collaboration. In terms of commissioning, clinically led approaches to planning and designing health services introduced in 2013 were seen as more likely to be both innovative and effective, however, the effective commissioning by the clinical commissioning groups have been hindered by three system barriers: lack of autonomy to make decisions that meet local needs, budget and resource constraints, and lack of support for tough prioritisation decisions (Robertson et al., 2016). In terms of regulation, the diabetes services were measured separately against different outcomes.

Also at the system level, the funding programmes rewarding development of innovative coordinated care services, including the Sustainability and Transformation Plans and the New Care Models Programme did not always meet with enthusiasm and support of the service providers what might impact on integration and leadership at organisational and transformation team levels. In the first case, the STP was seen as an opportunity by the integrated diabetes care transformation team but as the diabetes programme was advanced in its development, it had to be rethought to fit the priorities that occurred at the organisational level. Some may see it as disruptive to the work of the transformation team working within the bottom-up approach. Regarding the new care models, the status was awarded to some trusts across the country but not all, excluding the studied case, what meant that the resources have been allocated inconsistently across the country.

Overall, the system level leadership promoted integration and local leadership for integration, however, the environment with limited resources, not fully developed regulation, payment and incentive regimes, and the local services and individual service providers not being motivated enough to take risks and commit resources to integration, brought challenges to execute the recommendations. Additionally, the national programmes with valuable aims and objectives did not always match what was needed locally and what was already achieved. One could argue that this type of environment provides flexibility to develop programmes suitable to the local needs of services and leaders. However, it seems that leadership for integrated care is supported by vision but not necessarily solutions that the local leaders having a task of addressing and convincing the otherwise separate and independent organisations could utilise.

At the organisational level, leadership on the project did not have a clear structure throughout the organisation and was not explained to those who were expected to be led and be leaders (with often two functions joint). Without clear leadership it was difficult for a clear vision of a new service and stakeholders' role in it. If leadership for integration is coming from other source than upper level management, it needs to be supported at this level to be supported with a decision- 
making structure and provided with appropriate resources including project management (Ham and Walsh, 2013). In the studied project, this gap has made it difficult for leadership at the transformation team level to flourish.

At the transformation team level, 'shared/collective/collaborative' leadership for integrated care was a postulate rather than a reality. The participants still expected someone, one person, to 'fill in a void,' 'chair a meeting,' and provide 'strong leadership.' And while there was understanding that the team needs more than 'a single leader' and 'a unitary person' for the project to succeed, there was not much clarity on how to proceed. In the end, after three years of working together, the idea of 'leaders in each organisation and each setting' was still only a demand. Since the study took place, this was negotiated and modified with healthcare practitioners cooperating in new ways (e.g., through the multidisciplinary team meetings) and taking up leadership roles centred around improving diabetes service. It is less and less about 'me in my organisation' with more focus on 'me in the system,' hopefully moving towards 'us for the patient.'

\section{The challenges to aligning leadership at all levels}

The studied case identified factors responsible for making leadership not fully aligned at the system, organisational and transformation team levels. Healthcare integration was promoted by the system level leaders, reflected in the national level policies, and followed by selected, nominated and funded projects to develop and test new models of care and contractual arrangements. It seems that the system level leadership for integration, although directed at all providers of healthcare considered to benefit from increased coordination of care, was not inclusive of all projects but only of the chosen ones. In the system created with the top-down approach there was little support for projects initiated locally in response to the local needs and searching for the local solutions; on one hand the health services were expected to integrate (as per the national policies) but on the other hand they were expected to wait till the piloted and improved models of care are rolled out across the country.

The studied local project who responded to the national policy call, and local policy calls aligned with the national policies as would be expected, found itself in a difficult position of balancing conflicting messages from the top with the aspirations of the local healthcare providers and receivers. The tensions at the organisational and transformation team levels were a response to this inconsistent system level leadership. In this context, the organisational level leadership was constrained by:

- operating in the times of uncertainty

- operating in the times of scarce resources for transformation

- operating in the times of prioritising savings over investment

The transformation team, taking responsibility for driving the change, was in a vulnerable position of developing a new service without the necessary support. Leadership alignment for full integration of primary and specialist care was challenged by:

- lack of evidence-based guidelines and resources to develop and implement the new service

- lack of evidence-based guidelines and resources to develop and maintain leadership within the team and establish its role against the organisational and system level leadership

- lack of clear communication pathways with the organsational level leadership

- lack of decision making pathways

- the tension between clinical leadership and middle and upper level managers

- the assumed leadership by the team members, the arrangements not being clear, maybe the problem of not being trained or reflective on what leadership is needed, not evaluating as the project was progressing

- personnel changes 
The first explanation of the leadership not being aligned is the clash between the system level plan developed by NHS England, and the local aspirations. The national plan was to be selective in developing and testing the new models of care and to be non-prescriptive with solutions to enable local adjustments (NHS England, 2014b). The second explanation is more extreme in thinking, suggesting that the system level policies of integrated care work as a discourse to manage tensions associated with healthcare funding and not as an intervention that can achieve most desired outcomes (e.g. a reduction in hospital admissions) (Hughes, 2017). The third explanation suggests that the alignment is never really possible because of the different value sets present at different levels of leadership with the policy domain being responsible to the electorate, management addressing corporate accountability, and the healthcare professionals seeking the best service for patients (De Burca, 2008). The fourth explanation is related to leadership within the transformation teams and a gap in the literature and practical advice on how to arrange and maintain effective functioning of the teams to be able to drive the change within the constraints imposed by the system and organisational level leadership; the insights into the practicalities of functioning of the transformation teams are rare (e.g. Lejeune \& Vas, 2011) with the literature on mergers and acquisitions in the private sector bringing some suggestions around a need for a strategy on managing change and people involved (Steigenberger, 2017) with a call for more research into integration project management, integration team composition, and temporal dynamics within integration projects (Nguyen \& Kleiner, 2003).

\section{Practical implications}

This case study highlights the importance of clarifying the leadership model when developing an integrated service and aligning leadership at the system and organisational levels of change. It also emphasises the significance of establishing leadership at the transformation team level and working out practicalities of collaborating when deciding on the specifications of the new service.

Although the system level leadership for integration may not be easy to influence, the following steps may help to build leadership at the organisational level to determine what and how can be achieved:

- know the decision making structure in all organisations involved and identify the managerial leaders: clarify who will make the final decisions about the implementation of the service and align decision making process across all organisations with indication who on the transformation team needs to communicate what to whom

- check if all leaders have project management support so that the message from all organisations is well informed

- held regular meetings ( as the transformation team) with feedback from action points

- divide the project into smaller tasks requiring cooperation and celebrate successes

- establish if all leaders share the vision and accept their new roles

- strong clinical leadership voiced at the meetings but also clinical practice in everyday interaction across organisations

- face-to-face engagement with providers of care to collect their views and address their concerns

- engagement with providers of care focused on supporting them, working together to improve quality of care, sharing good practice and avoiding shaming those who do not achieve

\section{Key points:}

- the importance of aligned leadership for integration at the system and organisational levels with leadership at the transformation team level driving change locally 
- the gap between the rhetoric and reality of the system level leadership for integration of healthcare may hinder full integration of projects functioning independently of the nationally funded programmes

- the principles of leadership for integration, for example a system leadership considered fit for the purpose of working across professions and organisations, need to be followed with practical solutions to organise and manage the transformation teams

- there is a need for practical guidelines and step-by-step toolkits to support the local leaders in integrating care 


\section{References:}

Aarons, G.A., Farahnak, L.R., Ehrhart, M.G and Sklar, M. (2014) 'Aligning Leadership Across Systems and Organizations to Develop Strategic Climate to for Evidence-Based Practice Implementation,' Annu Rev Public Health, 3(35), pp.255-274. doi:10.1146/annurev-publhealth032013-182447

Baker, G.R. (2011) The roles of leaders in high-performing health care systems. London: The King's Fund.

British Medical Association (2017a) New models for delivering care. Contractual models for integrated care MCP and PACS contracts. Available at:

https://www.bma.org.uk/-

/media/files/pdfs/collective\%20voice/policy\%20research/nhs\%20structure\%20and\%20delivery/i ntegrated-provider-models.pdf?la=en (Accessed 11 December 2018)

British Medical Association (2017b) New models for delivering care. Payment models for integrated care. A capitated payment approach. Available at:

https://www.bma.org.uk/-

/media/files/pdfs/collective\%20voice/policy\%20research/nhs\%20structure\%20and\%20delivery/p ayment-models-for-integrated-care.pdf?la=en (Accessed 11 December 2018)

British Medical Association (2015) General practice and integration: Becoming architects of new care models - A paper for discussion. Available at: https://www.bma.org.uk/-

/media/files/pdfs/working\%20for\%20change/negotiating\%20for\%20the\%20profession/general\% 20practitioners/general\%20practice\%20and\%20integration\%20apr\%202015.pdf (Accessed 22

November 2018)

Calciolari, S. \& Ilinca, S. (2011) 'Comparing (and learning from) integrated care initiatives: an analytical framework,' Journal of Integrated Care, Vol. 19 Issue: 6, pp.4-13. Doi:

$10.1108 / 14769011111191412$

Chreim, S, Williams, B.E., Janz, L. \& Dastmalchian, A. (2010) 'Change agency in a primary health care context: The case of distributed leadership,' Health Care Management Review, 35(2), pp.187-199. doi: 10.1097/HMR.0b013e3181c8b1f8

Crowe, S., Cresswell, K., Robertson, A., Huby, G., Avery, A. \& Sheikh, A. (2011) 'The case study approach', BMC Med Res Methodol, 11(100). doi:10.1186/1471-2288-11-100

De Burca, S. (2008) Alignment and variation in managerial and professional perceptions of purpose, leadership roles and outcomes in a healthcare organisation's change programme. The Irish Journal of Psychology, 29(1-2), pp. 45-59.

Department of Health and Social Care (2015) The NHS Constitution for England. Available at: https://www.gov.uk/government/publications/the-nhs-constitution-for-england/the-nhsconstitution-for-england (Accessed 22 November 2018)

Department of Health (2010). Equity and Excellence: Liberating the NHS. Available at: https://www.gov.uk/government/uploads/system/uploads/attachment_data/file/213823/dh_11779 4.pdf (Accessed: 6 November 2018)

Department of Health (2009). NHS 2010-2015: from good to great. Preventative, peoplecentred, productive. Available at: https://www.gov.uk/government/uploads/system/uploads/attachment_data/file/228885/7775.pdf (Accessed: 6 November 2018) 
Diabetes UK (2013) Best practice for commissioning diabetes services: An integrated care framework. Available at: https://diabetes-resources-production.s3-eu-west-

1.amazonaws.com/diabetes-storage/migration/pdf/best-practice-commissioning-diabetesservices-integrated-care-framework-0313.pdf (Accessed 20 November 2018)

Drath, W.H., McCauley, C.D., Palus C.J., Van Velsor, E., O’Connor, P.M.G., McGuire, J.B. (2008) Direction, alignment, commitment: Toward a more integrative ontology of leadership. The Leadership Quarterly, 19, pp.635-653.

Erens, B., Wistow, G., Durand, M.A., Mounier-Jack, S., Manacorda, T., Douglas, N., Hoomans, T., Mays, N. (2017) Evaluation of the Integrated Care and Support Pioneers Programme (20152020) Results from the first survey (spring 2016) of Pioneer key informants. Policy Innovation Unit. Available

at: http://piru.1shtm.ac.uk/assets/files/First\%20key\%20informant\%20survey\%20report.pdf (Accessed $11 \quad$ December 2018)

Ferlie, E.B. \& Shortell, S.M., (2001). Improving the quality of healthcare in the United Kingdom and the United States: a framework for change. The Milbank Quarterly, 79(2), pp.281-315.

Fillingham, D. and Weir, B. (2014). System leadership. Lessons and learning from AQuA's Integrated Care Discovery Communities. London: The King's Fund. Available at: https://www.kingsfund.org.uk/sites/default/files/field/field_publication_file/system-leadershipoctober-2014.pdf (Accessed: 6 November 2018).

Ham, C. \& Walsh, N. (2013) Making integrated care happen at scale and pace: Lessons from experience. London: The King's Fund. Available online:

https://www.kingsfund.org.uk/publications/making-integrated-care-happen-scale-and-pace (Accessed 11 December 2018)

Ham, C. \& Smith, J. (2010). Removing the policy barriers to integrated care in England. London: The Nuffield Trust. Available at: https://pdfs.semanticscholar.org/2344/51519ac16ab876aaadf492aad004ad2501ab.pdf (Accessed: 6 November 2018).

Health and Social Care Act 2012. Available at: http://www.legislation.gov.uk/ukpga/2012/7/contents/enacted (Accessed 6 November 2018).

Heifetz, R., Linsky, M. \& Groshow, A. (2009) The Practiceof Adaptive Leadership. Cambridge: Harvard Business School.

Hughes, G. (2017) New models of care: the policy discourse of integrated care. People, Place and Policy, 11(2): 72-89.

Irani, M. (2008). Integrated healthcare services. The future of commissioning and provision for out of hospital healthcare in the NHS. An NHS Alliance discussion document. Retford: NHS Alliance. Available at: https://www.networks.nhs.uk/nhs-networks/nhs-alliance-specialistsnetwork/documents/Integrated\%20healthcare\%20Jan08.pdf (Accessed 6 November 2018).

Kelley-Patterson, D. (2012). What kind of leadership does integrated care need? London J Prim Care, 5(1): 3-7.

Kozlowska, O., Lumb, A., Tan, G.D. \& Rea, R. (2018) 'Barriers and facilitators to integrating primary and specialist healthcare in the United Kingdom: a narrative literature review,' Future Healthcare Journal, 5(1), pp.64-80. 
Lejeune, C. \& Vas, A. (2011) 'Predictors of successful organisational change: The alignments of goals, logics of actions and leaders' roles to initiate clinical pathways,' International Journal of Care Pathways, 15(1), pp.4-14. doi:10.1258/jicp.2010.010m09

Leutz, W.N. (1999). Five Laws for Integrating Medical and Social Services: Lessons from the United States and the United Kingdom. The Milibank Quarterly, 77(1), pp.77-110.

Miles, M.B. \& Huberman, M. (1994) Qualitative data analysis: an expanded sourcebook. CA: Sage Publications Inc.

Morse, N. (2018) Developing new care models through NHS vanguards. London; National Audit Office. Available at: https://www.nao.org.uk/wp-content/uploads/2018/06/Developing-new-caremodels-through-NHS-Vanguards.pdf (Accessed 11 December 2018)

National Voices \& Think Local Act personal (2013) A narrative for person-centred coordinated care. London: NHS England. Available at:

http://www.nationalvoices.org.uk/sites/default/files/public/publications/narrative-for-personcentred-coordinated-care.pdf (Accessed 6 November 2018)

Nguyen, H. and Kleiner, B.H. (2003) The effective management of mergers. Leadership \& Organization Development Journal, Vol. 24 Issue: 8, pp.447-454.

NHS England (2016a) Integrated primary and acute care systems (PACS) - Describing the care model and the business model. Available at: https://www.england.nhs.uk/wp-

content/uploads/2016/09/pacs-framework.pdf (Accessed 11 december 2018)

NHS England (2016b) The multispecialty community provider (MCP) emerging care model and contract framework. Available at: https://www.england.nhs.uk/wp-

content/uploads/2016/07/mcp-care-model-frmwrk.pdf (Accessed 11 December 2018)

NHS England (2014a) Integrated Care and Support Pioneer Programme. Available at: https://www.england.nhs.uk/pioneers/wp-content/uploads/sites/30/2015/03/icase-one-year-on.pdf (Accessed 11 December 2018)

NHS England (2014b) Five Year Forward View. Available at: https://www.england.nhs.uk/wpcontent/uploads/2014/10/5yfv-web.pdf (Accessed 6 November 2018).

NHS Improving Quality (2013) An Introduction to the NHS Change Model. Available at: http://www.nhsggc.org.uk/media/235711/change-and-improvement-

nhs_change_model_july20131.pdf

NHS Leadership Academy (2011) The Clinical Leadership Competency Framework. Available at:

https://www.leadershipacademy.nhs.uk/wp-content/uploads/2012/11/NHSLeadership-

Leadership-Framework-Clinical-Leadership-Competency-Framework-CLCF.pdf (Accessed 6 November 2018).

Northouse, P.G. (2007) Leadership Theory and Practice , 4th ed., Sage Publications Inc., Thousand Oaks, CA.

Parks, S.D. (2005) Leadership Can Be Taught: A Bold Approach for a Complex World. Cambridge: Harvard Business School. 
RAND Europe \& Ernst \& Young LLC (2012) National Evaluation of the Department of Health's Integrated Care Pilots. Final report: full version. Rand Cooperation. Available at:

https://assets.publishing.service.gov.uk/government/uploads/system/uploads/attachment_data/file 1215103/dh_133127.pdf (Accessed 11 December 2018)

Reid, P.P., Compton, W.D., Grossman, J.H., Fanjiang, G. \& Committee on Engineering and the Health Care System, Institute of Medicine and National Academy of Engineering (2005)

Building a Better Delivery System: A New Engineering/Health Care Partnership. Washington (DC): National Academies Press (US). Available at:

https://www.ncbi.nlm.nih.gov/books/NBK22878/ (Accessed 6 November 2018).

Robertson, R., Holder, H., Ross, S., Naylor, C. \& Machaqueiro, S. (2016) Clinical commissioning. GPs in charge? London: The King's Fund. Available at:

https://www.kingsfund.org.uk/sites/files/kf/field/field_publication_file/Clinical_commissioning web_pdf.pdf (Accessed 6 November 2018).

Royal College of General Practitioners (2013) The 2022 GP: A Vision for General Practice in the future NHS. Available at:

file:///C:/Users/p0085541/Downloads/The-2022-GP-A-Vision-for-General-Practice-in-theFuture-NHS\%20(1).pdf (Accessed 22 November 2018)

Royal College of General Practitioners (2012) General Practice and the integration of care. An RCGP policy report. Available at:

file://C:/Users/p0085541/Downloads/General_Practice_and-

the_Integration_of_Care\%20_An_RCGP_Report\%20(2).pdf (Accessed 22 November 2018)

Royal College of Physicians (2017) Delivering the future hospital. Full report. RCP London. Available at: file://C:/Users/p0085541/Downloads/FHC\%20final\%20report_0_0\%20(2).pdf (Accessed 7 December 2018)

Sanfey, J. (2017) 'The use of case studies to drive bottom-up leadership in community-oriented integrated care and health promotion (COIC),' London J Prim Care (Abingdon), 9(1), pp.7-9. doi:10.1080/17571472.2016.1271497

Senge, P.M. (1990) The Fifth Discipline: The Art and Practice of the Learning Organization. New York: Doubleday/Currency.

Shaw, S., Rosen, R. \& Rumbold, B. (2011). What is integrated care? Nuffield Trust. Available at:

http://www.nuffieldtrust.org.uk/sites/files/nuffield/publication/what_is_integrated_care_r esearch_report_june11_0.pdf(Accessed 6 November 2018).

Stake, R.E. (1995) The art of case study research. London: Sage Publications Ltd.

Stange, K.C. (2009) 'The problem of fragmentation and the need for integrative solutions,' Ann Fam Med, 7(2), pp.100-103.

Steigenberger, N. (2017) The Challenge of Integration: A Review of the M\&A Integration Literature. International Journal of Management Reviews, 19(4), pp.408-431.

The King's Fund (2016) Supporting integration through new roles and working across boundaries. London: The King's Fund. Available at:

https://www.kingsfund.org.uk/publications/supporting-integration-new-roles-boundaries

(Accessed 6 November 2018). 
The King's Fund (2015) The practice of system leadership. Being comfortable with chaos. London: The King's Fund. Available at:

https://www.kingsfund.org.uk/sites/default/files/field/field_publication_file/System-leadershipKings-Fund-May-2015.pdf (Accessed 6 November 2018).

The King's Fund (2011) The future of leadership and management in the NHS: no more heroes. Report from The King's Fund Commission on Leadership and Management in the NHS. London: The King's Fund. Available at: www.kingsfund.org.uk/publications/future-leadership-andmanagement-nhs (Accessed 6 November 2018).

Timmins, N. (2015). The practice of system leadership. Being comfortable with chaos. London: The King's Fund. Available at:

https://www.kingsfund.org.uk/sites/files/kf/field/field_publication_file/System-leadership-KingsFund-May-2015.pdf (Accessed 6 November 2018).

West, M., Armit, K., Loewenthal, L., Eckert, R., West, T. \& Lee, A. (2015a) Leadership and Leadership Development in Health Care: The Evidence Base. London: Faculty of Medical Leadership and Management. Available at: https://www.kingsfund.org.uk/sites/files/kf/field/field_publication_file/leadership-leadershipdevelopment-health-care-feb-2015.pdf (Accessed 6 November 2018).

West, M., Armit, K., Eckert, R., West, T. \& Lee, A. (2015b) Leadership in Health Care: A Summary of The Evidence Base. London: Faculty of Medical Leadership and Management. Available at: https://www.kingsfund.org.uk/sites/default/files/field/field_publication_summary/leadership-inhealth-care-apr15.pdf (Accessed 11 December 2018)

West, M., Eckert, R. Steward, K. \& Pasmore, B. (2014). Developing collective leadership for health care. London: The King's Fund/Centre for Creative Leadership. Available at: https://www.kingsfund.org.uk/sites/default/files/field/field_publication_file/developingcollective-leadership-kingsfund-may14.pdf (Accessed 6 November 2018).

Yin, R.K. (2009) Case study research, design and method. London: Sage Publications Ltd.

Appendix 1. National policies - policy documents relevant to health services integration 2006-2016

Primary legislation (2)

National Health Services Act (2006)

https://www.legislation.gov.uk/ukpga/2006/41/contents

Health and Social Care Act (2012)

http://www.legislation.gov.uk/ukpga/2012/7/contents/enacted

Recommendations to the government (3)

Integration: A Report from the NHS Future Forum (2012)

https://webarchive.nationalarchives.gov.uk/20130805113156/https://www.gov.uk/government/uploads/system/uploads/attachment_data/file/2 16425/dh_132023.pdf

NHS Future Forum Summary Report: Second phase overarching report (2012)

https://assets.publishing.service.gov.uk/government/uploads/system/uploads/attachment_data/file/216422/dh_132085.pdf

NHS Future Forum Summary Report on proposed changes to the NHS (2011)

https://assets.publishing.service.gov.uk/government/uploads/system/uploads/attachment_data/file/213748/dh_127540.pdf 


\section{Department of Health (6)}

The Mandate: A mandate from the Government to NHS England for April 2015-March 2016 (2015)

https://assets.publishing.service.gov.uk/government/uploads/system/uploads/attachment_data/file/486818/mndate-NHSE-15_16.pdf

The Mandate: A mandate from the Government to NHS England for April 2014-March 2015 (2014)

https://assets.publishing.service.gov.uk/government/uploads/system/uploads/attachment_data/file/383495/2902896_DoH_Mandate_Accessibl e_v0.2.pdf

The Mandate: A mandate from the Government to the NHS Commissioning Board: April 2013- March 2015 (2013)

https://assets.publishing.service.gov.uk/government/uploads/system/uploads/attachment_data/file/256497/13-15_mandate.pdf

Long Term Conditions Compendium of Information: Third Edition (2012)

https://assets.publishing.service.gov.uk/government/uploads/system/uploads/attachment_data/file/216528/dh_134486.pdf

Interim measures for Patient Experience at the interfaces between NHS services (2012)

https://assets.publishing.service.gov.uk/government/uploads/system/uploads/attachment_data/file/212896/Interim-Integration-Measures-for-

Patient-Experience.pdf

Equity and Excellence: Liberating the NHS (2010)

https://assets.publishing.service.gov.uk/government/uploads/system/uploads/attachment_data/file/213823/dh_117794.pdf

NHS Next Stage Review. Our vision for primary and community care. (2008)

http://www.nhshistory.net/dhvisionphc.pdf

\section{NHS Strategy Documents (2)}

Five Year Forward View (2014)

https://www.england.nhs.uk/wp-content/uploads/2014/10/5yfv-web.pdf

The NHS Constitution for England (2009, updated in 2015)

https://www.gov.uk/government/publications/the-nhs-constitution-for-england/the-nhs-constitution-for-england

\section{Patient perspective (3)}

National Voices, A Narrative for Person-Centred Coordinated Care (2013)

https://www.nationalvoices.org.uk/publications/our-publications/narrative-person-centred-coordinated-care

National Voices, Principles for integrated care (2013)

https://www.nationalvoices.org.uk/sites/default/files/public/publications/principles_for_integrated_care_20111021.pdf

National Voices, Integrated care: what do patients, service users and carers want? (2013)

https://www.nationalvoices.org.uk/sites/default/files/public/publications/what_patients_want_from_integration_national_voices_paper.pdf

\section{Guidance relating to payment mechanisms, costing and joint financing across healthcare (6)}

Integrated care licence condition: guidance for providers of NHS funded services (2015)

https://assets.publishing.service.gov.uk/government/uploads/system/uploads/attachment_data/file/418493/IC_licence_condition_mar15.pdf

Delivering better integrated care (2014)

https://www.gov.uk/guidance/enabling-integrated-care-in-the-nhs

How can the NHS payment system do more for patients? (2013)

https://assets.publishing.service.gov.uk/government/uploads/system/uploads/attachment_data/file/302433/How_can_the_NHS_payment_syst em_do_more_for_patients_0.pdf

A fair playing field for the benefit of the NHS's patients: Monitor's independent review for the Secretary of State for Health (2013)

https://assets.publishing.service.gov.uk/government/uploads/system/uploads/attachment_data/file/284634/The_Fair_Playing_Field_Review_F

INAL.pdf

Enablers and barriers to integrated care and implications for Monitor (2012)

https://assets.publishing.service.gov.uk/government/uploads/system/uploads/attachment_data/file/287800/Enablers_and_barriers_to_integrate d_care_report_June_2012.pdf

An Evaluation of the Reimbursement System for NHS-funded care: A report for Monitor (2012) 
https://assets.publishing.service.gov.uk/government/uploads/system/uploads/attachment_data/file/285988/Evaluation_Report__Full_Report_FINAL.pdf

\section{NHS Planning Documents (technical guidance) (6)}

NHS England, Delivering the Forward View: NHS Planning Guidance 2016/17-2020/21 (2015)

https://www.england.nhs.uk/wp-content/uploads/2015/12/planning-guid-16-17-20-21.pdf

NHS Commissioning Board, Enhanced Service Specification Risk Profiling and Care Management Scheme (2013) https://www.england.nhs.uk/wp-content/uploads/2013/03/ess-risk-profiling.pdf

NHS Commissioning Board, Commissioning fact sheet for clinical commissioning groups (2012) https://www.england.nhs.uk/wp-content/uploads/2012/07/fs-ccg-respon.pdf

NHS England, Everyone Counts: Planning for Patients 2013/14 (2012) https://www.england.nhs.uk/wp-content/uploads/2013/12/5yr-strat-plann-guid.pdf

Department of Health, The Operating Framework for the NHS In England 2012/13 (2011) https://assets.publishing.service.gov.uk/government/uploads/system/uploads/attachment_data/file/216590/dh_131428.pdf

Department of Health, Technical Guidance for the 2012/13 Operating Framework (2011) https://assets.publishing.service.gov.uk/government/uploads/system/uploads/attachment_data/file/216413/dh_132045.pdf

\section{British Professional Bodies, Royal Colleges representing healthcare professionals (5)}

Royal College of General Practitioners, Responding to the needs of patients with multimorbidity. A vision for general practice (2016) http://www.rcgp.org.uk/-/media/Files/Policy/A-Z-policy/RCGP-Responding-to-needs-of-Multimorbitiy-2016.ashx?la=en

British Medical Association England, General practice and integration: Becoming architects of new care models - A paper for discussion. (2015) https://www.bma.org.uk/-

/media/files/pdfs/working $\% 20$ for $\% 20$ change/negotiating $\% 20$ for $\% 20$ the $\% 20$ profession/general\%20practitioners/general\%20practice $\% 20$ and $\%$ 20integration\%20apr\%202015.pdf

Royal College of General Practitioners, General Practice and the integration of care. An RCGP policy report. (2012) http://www.rcgp.org.uk/-/media/Files/Policy/A-Z-policy/General_Practice_and-the_Integration_of_Care-_An_RCGP_Report.ashx?la=en

Royal College of General Practitioners, The 2022 GP: A Vision for General Practice in the future NHS. (2013)

http://www.rcgp.org.uk/policy/rcgp-policy-areas/general-practice-2022.aspx

Future Hospital Commission, Future Hospital: Caring for Medical Patients. Report for the Royal College of Physicians (2013) https://www.rcplondon.ac.uk/projects/future-hospital-commission

\section{Appendix 2. Local policies}

OUH Integrated Business plan 2014/15-2018/19 (2013)

https://www.ouh.nhs.uk/about/publications/documents/business-plan-2013.pdf

OH Strategic Plan Summary Document for 2014-19 (2013)

https://assets.publishing.service.gov.uk/government/uploads/system/uploads/attachment_data/file/392928/OXFORD_HEALTH_Publishabl e_Summary_Strategic_Plan_1415.pdf

OCCG Strategy and Plan 2014/15-2018/19 (2013)

https://mycouncil.oxfordshire.gov.uk/documents/s24544/HWB_MAR1314R09.doc.pdf

BOB Sustainability and Transformation Plan (2016)

https://www.bobstp.org.uk/media/1036/public_summary_final.pdf

Oxfordshire Healthcare Transformation Programme The case for change brochure (2016)

$\mathrm{http}: / / \mathrm{www}$.oxonhealthcaretransformation.nhs.uk/what-is-the-vision/consultation-documents/64-the-case-for-change-brochure/file

Oxfordshire Healthcare Transformation Programme Integrated Impact Assessment: Post-consultation report (2017)

http://mycouncil.oxfordshire.gov.uk/documents/s38264/JHO_AUG0717R11\%20-

\%20Integrated\%20Impact\%20Assessment\%20Report.pdf 